\title{
Representations of Maghrebians' Immigrant Life in France in Two Literary Generations: A Multilevel Cognitive Stylistic Reading of Driss Chraibi's Les boucs and Azouz Begag's Le gone du Chaaba
}

\author{
Khalid Majhad \\ Hassan II Casablanca University, Morocco \\ e-mail: kh.majhad@gmail.com
}

\begin{abstract}
While political analysts, economists, cultural studies scholars have all been offering insightful analyses of the different matters relating to immigrant life in different parts of the world, this article reaches for a first-hand testimony in two autobiographical novels by two internationally recognized Maghrebian novelists who respectively represent the first and second generations of Maghrebian immigrants in France. In a rather innovative manner, the portrayal of immigrant life in the two novels is analyzed from a cognitive stylistic perspective, and informed by the author's multiple research viewpoints, those of a Maghrebian literature critic, a francophone postcolonial studies researcher and a frequent visitor to France carrying the concerns of an extended family based there. The interest in style during our close reading of these largely autobiographical narratives is based on the assumption that an author's style is a reflection of their attitude and worldview. Chraibi's novel Les Boucs (1955) is as timely now as it was in the day of its first appearance for its balanced and largely objective analysis of the sociological, psychological and economic conditions of North African immigrants. Stylistically, Les boucs features a close correlation between its form and content in that the chaotic nature of immigrant life is formally embodied in Chraibi's non-linear mode of writing. In contrast to the bleak picture presented throughout Chraibi's text, Begag's convivial approach oozes hope for his readers who come to realize the futility of continuing to curse the state of deprivation and inequity while there can always be ways setbacks can be turned into opportunities. The study uses a qualitative method of stylistic analysis and applies the two necessary principles of 'contextualization' and 'comprehensiveness' to ensure a high degree of analytical and interpretive validity.

Keywords: Azouz Begag, congnitive stylistics, Driss Chraibi, Francophone Maghrebi novel, Les boucs, Le gone du chaaba
\end{abstract}




\section{Khalid Majhad}

\section{INTRODUCTION}

Immigration and its many associated problems has been a major theme treated by Maghrebian novelists across generations. Cosmopolitan France has been a main destination for Maghrebi immigrants over the years, though it is still true that none of the successive generations of immigrants has been successful in achieving full integration in the French society. In fact, there is no one simple explanation to the problems facing immigrants. Many would consider racism and the 'psychological traumas' of colonization as major factors. While political analysts, economists, cultural studies scholars have all offered their insightful analyses of the various matters related to immigrant life in different parts of the world, this article reaches for a first-hand testimony in two autobiographical novels by two internationally recognized Maghrebian novelists who respectively represent the first and second generations of Maghrebian immigrants in France. In a rather innovative manner, the portrayal of immigrant life in the two novels is analyzed from a cognitive stylistic perspective, and informed by the author's multiple research viewpoints, i.e. being a Maghrebian literature analyst, a francophone postcolonial studies researcher and a frequent visitor to France carrying the concerns of an extended family based there.

The interest in style during our close reading of these largely autobiographical narratives is based on the assumption that an author's style is a reflection of their attitude and worldview. According to Boase-Beier (2010), the stylistic features of a text embody the clearest expression of the 'author's mental state' under certain social, cultural and ideological influences. The aftermath of colonialsm is no doubt a concern shared by every Maghrebian author across generations. It is a main component of what is now referred to as the 'stylistic context', which implies that every author's or text's style is unavoidably socialised, culturalised, historicised, conceptualised, mentalised and womanised, as it were' (Ghazala, 2011, p. 16).

Immigrant life as a literary theme has been more prominent in the works 'Beur' writers, who essentially belong to the second and third generations of Maghrebi immigrants. The term 'Beurs' originally refers to the descendants of illiterate manual workers, thereby excluding the privileged children of well-positioned families of doctors, lawyers and engineers, etc. The situation of the Beurs is much more complex than that of their parents; they were born and raised in France, and received western education but unfortunately not granted equal opportunities as those enjoyed by the 'Français de souche' [pure French natives] (Orlando, 2002, p. 59). Beur literature is manly about the plights of a life lost between two worlds (60). Azouz Begag's two novels Le gone du Chaaba (1986) et Béni ou le Paradis Privé (1989) are considered to be the early writings qualified as Beur texts. Both novels 'offer a window into the lives of young boys growing up in urban settings where they must fight for acceptance in a world where all odds are against them' (p. 60).

However, the problems facing the Beurs today are not totally new but were part of the life of their predecessors, the immigrant workers whom Driss Chraibi was the first to depict in his novel Les boucs (1955). This novel marked a thematic transition in Chraibi's works. After Le passé simple (1954) in which he condemned all the forms of 'underdevelopment, social injustice, and hypocrisy which he ascribes to both colonialism and Islamism in his home country, Morocco, Chraibi shifts to a scathing criticism of France's hypocrisy represented by 'the wedge between the values of liberty, fraternity, and equality that the 
French tout and their actual treatment of North African immigrant workers [...] who always remain by French standards mere Arabs/Berbers, uncivilized, backward, and undeserving of equal rights' (Moukhlis, 2001, p. 100).

\section{LITERATURE REVIEW}

From the time of Driss Chraibi to the present time of Azouz Begag a lot of social developments have taken place both inside France and around the world. The only thing that seems to persist is the uneasy situation of North African immigrants. The tension between the French state and French nationals regarding the increasingly worrying presence of immigrants on the one hand, and the constant confrontations with the immigrants themselves on the other are complex matters that should be analyzed objectively and without emotional bias. There is obviously a heated situation in Metropolitan France today that requires a reasoned debate open to different stances, particularly that the management of immigration and the need for coexistence are no longer a matter that can be left to the state alone, but a fact of life that all the components of French society should learn to accept and adapt to. The one point this article emphasizes, inspired by the reported lives of the two authors in their autobiographies, is that the successes or failures of Maghrebian immigrants are actually revealing stories for both the Maghrebian and French readers to contemplate.

The two texts are written in different periods by two authors belonging to two different generations and both describe a first-hand experience with immigrant life. They also both have ambitions beyond those of their enclosed communities which are immersed in a daily search for material means to survive. Setbacks come against them from all directions, from within due to the defeatist attitudes of compatriots and from the state that fails to recognize Maghrebians as being capable of integration and assimilation of the modern values of the French society. While Chraibi was the mouthpiece for the first generation of Maghrebian immigrants in France, Azouz Begag, is one of the initiators of the Beaur literary movement which addresses the issues confronting the second and third generations of Maghrebi immigrants born in France.

In addition to being thematically connected, the two texts could be read as complementary narratives, with young Azouz fulfilling to some extent the suppressed desires of his ancestors whom Chraibi represents. Besides, while Les boucs lays emphasis on the outside cultural and social factors impeding integration and self-realization, Le Gone du Chaaba (1986) redresses the balance of Chraibi's critique by dwelling more specifically on the inner psychological defeats immigrants themselves live by, to the extent that they even come to conceive of a successful Maghrebian as 'un faux-frère' and a traitor. Metaphorically, Begag focuses on the inner enemy haunting his compatriots. As LayChenchabi and Do (2011) have explained, it is an ironical fact of Maghrebian communities in general that the ambition to do well in school represents a major break with one's community and sets one up as a traitor for trying to be 'comme les Français' [like the French], and that 'to be praised by a French teacher at the expense of one's brothers in the classroom is very similar to siding with the French against one's own people' (p. 42). 
Khalid Majhad

\begin{tabular}{|c|c|}
\hline Original French Text & English Translation \\
\hline C'est normal, c'est pas un Arabe. Les autres & It's normal, He is not Arab. The others agree. \\
acquiescent. & - Yes! I am ARAB! \\
- Si ! Je suis un Arabe ! & - If you were one, you'd be like us, ranking \\
- Si t'en étais un, tu serais dernier de la classe & And Nasser resumes: \\
comme nous ! fait Moussaoui. & - Yeah, yeah, why are you not ranking last \\
Et Nasser reprend : & with us? The French teacher put you second, \\
- Ouais, ouais, pourquoi que t'es pas dernier avec & with the French; that's normal because you're \\
nous ? Il t'a mis deuxième, toi, avec les & not Arab but a Gaouri like them. \\
Français, c'est bien parce que t'es pas un & - No, I'm Arab. I work well, that's why I \\
Arabe mais un Gaouri comme eux. & have a good ranking. Everyone can be like \\
- Non, je suis un Arabe. Je travaille bien, c'est & me. (My Trans.) \\
pour ça que j'ai un bon classement. Tout le & \\
monde peut être comme moi. & \\
(Le gone du Chaaba, p.98) & \\
\hline
\end{tabular}

Back to Chraibi, what exacerbates his protagonist and fuels his aggressiveness is the non-recognition of his distinctiveness as a learned writer. The number one source of trouble for the French society even now is that these immigrants 'are rarely depicted as individuals, but simply as a pack or a crowd along with the fear and imminent danger that their images evoke. The immigrants are homogeneously stigmatized as North Africans. When one of them is suspected of committing a crime, he is reported to the police and referred to as the "North African'. (Bahri, 2014, p.66).

However, there comes a point in the narrative where Chraibi's attitude gets completely subverted in the middle of a sincere and thought-provoking conversation with his French lover, Isabelle. That was a turning point Chraibi could not help but give the whole matter a second thought. She shocked him with a relative truth everyone else would admit though not so openly.

\section{Original French Text}

- Exploitation de l'Arabe par l'Européen, oui, martelat-elle avec un rire aigu. Je les condamne certes, ceux-là qui vous ont chassés de chez vous, ne savent plus quoi faire de vous, pas même vous prendre en pitié. Oui, je sais faire la part des choses, généraliser et reconnaître que notre civilisation n'a su que vous désespérer. Oui, j'ai honte d'être une Européenne. Mais c'est vous, NordAfricains, que je condamne le plus. Parce que vous vous êtes toujours laissé faire. Vous avez toujours été en état d'exploitation, vous aimez bien qu'on vous exploite. Mais même chez vous, même avant les Français, de tout temps vous n'avez jamais été que cela : des bâtards d'hommes que tout le monde se passe de main en main, de génération en génération, de siècle en siècle, comme une terre ; Phéniciens, Grecs, Romains, Wisigoths, Vandales, Arabes, Turcs, Francs... (Les boucs, p.88)

\section{English Translation}

The exploitation of Arabs by Europeans, yes, she said emphatically with a bitter laugh. 'I do condemn them, those people who drove you your homes, who don't know what to do with, and don't even have pity on you. Yes, i can take sides, generalize, and recognize that our civilization makes you despair. Yes, I am ashamed to be European, but it is you North Africans yourselves that I condemn the most. You have always let yourselves be exploited, and you have always been expolited. Long before the French got you, you were nothing more than bastards that everybody passed from one to the other, generation after generation, centry after centry, like a plot of ground; phonecians, Greeks, Romans, Vsigoths, Vandals, Arabs, Turks, French... (The butts, p. 116) 
This same view is reiterated by Begag's French teacher in reaction to a Maghrebian student's revolt.

\begin{tabular}{|l|l|}
\hline \multicolumn{1}{|c|}{ Original French Text } & \multicolumn{1}{c|}{ English Translation } \\
\hline - Vous êtes tous des racistes ! hurle-t-il. C'est parce & - You are all racists! He yells. It's because we are \\
qu'on est des Arabes que vous pouvez pas nous & Arabs that you do not respect us! Mr. Grand has \\
sentir ! M. Grand a les cartes en main. Il attaque : - & the cards in his hand. He attacks: - Do not try to \\
Ne cherchez pas à vous défendre comme ça. La & defend yourself like that. The truth is that you are a \\
vérité, c'est que tu es un fainéant et que les fainéants & lazy idiot and that idlers like you never do anything \\
comme toi ne font jamais rien dans la vie. - Quel & in life. - What a fag! Moussaoui turns to Nasser. \\
pédé ! fait Moussaoui en se tournant vers Nasser. Il & He thinks we did not understand why he always \\
croit qu'on n'a pas compris pourquoi il nous mettait & put us last in class rankings...Look at Azouz. (All \\
toujours derniers au classement... Regardez Azouz. & heads turn to me then.) He is also an Arab and yet \\
(Toutes les têtes se tournent alors vers moi.) C'est & he is second in the class. So, do not look for an \\
aussi un Arabe et pourtant il est deuxième de la & excuse. You are just a lazy idiot. (My Trans.) \\
classe. Alors, ne cherchez pas d'alibi. Vous n'êtes & \\
qu'un idiot fainéant. (Le gone du Chaaba, p. 98) & \\
\hline
\end{tabular}

\section{RESEARCH METHODS}

As stated earlier, this article searches beyond the usual analyses of politicians, economists and cultural studies scholars for a genuine first-hand testimony about the various matters related to immigrant life in different parts of the world, hence the choice of two autobiographical novels by two internationally recognized Maghrebian novelists who respectively represent the first and second generations of Maghrebian immigrants in France. In a rather innovative manner, the portrayal of immigrant life in the two novels is analyzed from a cognitive stylistic perspective, and informed by the author's multiple research viewpoints, i.e. being a Maghrebian literature analyst, a francophone postcolonial studies researcher and a frequent visitor to France carrying the concerns of an extended family based there.

The study uses a qualitative method of stylistic analysis. In agreement with the stipulations of qualitative researchers, the study applies the two necessary principles of 'contextualization' and 'comprehensiveness' to ensure a high degree of analytical and interpretive validity (Saldanha \& O'Brien, 2013), The first means that all contextual factors surrounding the production of the two novels are brought to bear on the analysis, while comprehensiveness refers to the thorough examination of all the relevant textual details and stylistic choices informing the analyst's interpretation. The levels of textual salience which will be focused on for our stylistic analysis are: the flow and organization of the narration, lexical choice particularities, syntactic markedness and rhetorical devices, and these are presented as clues to the two authors' worldviews and thoughts about the existential dimensions of immigrant life.

\section{FINDINGS}

\subsection{Immigrant Life in Chraibi's Narrative: A Cognitive Stylistic Analysis}

Chraibi's novel Les boucs came after his landmark debut novel Le passé simple which slammed Moroccan patriarchal society. This novel was for critics a most powerful testimony to Chraibi's profound intellectuality and creative literariness. Chraibi's treatment of the intricacies of immigrant life in this novel was unprecedented in dramatising the social and 


\section{Khalid Majhad}

psychological dimensions of the protagonist's world. He decried in the strongest terms the injustices of metropolitan France vis-à-vis Maghrebian immigrants.

Chraibi's compellingly chaotic, non-linear, writing style brings readers close to the chaotic nature of the life led by immigrants. He simultaneously connects the social and psychological dimensions of his compatriots. The story line captures the sentimental and carnal attachment of a Frenchwoman to a cursed Arab, the terrible living conditions of twenty immigrants who sleep inside an old truck, and especially the situation of the narrator who strives to fulfill his vocation of a writer so he could better recount the distress of his compatriots (Aerts, 2016, p.15).

Having argued that style is a reflection of his attitude and mental state, we sense as readers, right from the opening lines of the novel, something peculiar about the writing style of Driss Chraibi and his rebellious attitude. It is extremely violent, to say the least. The issues he chooses to deal with throughout his career, i.e. immigration, patriarchy, religion and the cultural conflicts between the Western and the Arab world in general make of him an 'anarchist' (Bahri, 2014, p.64). Chraibi belongs to 'la génération 52', together with a number of founding figures such as Mouloud Mammeri, Mohamed Dib, Albert Memmi, Malek Haddad, Ahmed Sefraoui, Kateb Yacine, and Assia Djebar, etc., 'qui est née à la veille de l'indépendance du Maghreb et qui faisait partie de la première vague d'écrivains maghrébins révoltés' [was born on the eve of independence and made up the first camp of revolting writers] (Ben Mbarek, 2015, p. 11).

Chraibi's fictional heroes largely reflect his own self. In Les boucs, the protagonist is a learned immigrant who carries the hopes and aspirations of the entire community of Maghrebian migrants in France. Yalann, 'instruit de la langue française écrite, rêve d'être la voix des sans voix, l'éveilleur de conscience dont l'ambition est de redonner une "âme" aux émigrés, les inciter, aussi, à 'se révolter' [versed in French, dreams of becoming the voice that speaks for the voiceless, a consciousness awakener whose ambition is to give a 'soul' to the emigrants and to incite them to revolt] (Cailler, 1996, p. 2) [italics for emphasis]. However, unlike his compatriots who only seek shelter and little means for survival, Yalann Waldik strives to establish a career as a writer of a book that portrays the psychological traumas and disillusionments of his compatriots all along the regrettable journey to the presumed 'land of plenty'.

Chraibi's style forces the reader into a chaotic circle of non-linear events and adventures here and there, with connecting threads hardly predictable. Cailler (1996) takes note of the way Chraibi extends readers' disarray up until the very last page where he reveals a most significantly symbolic incident that initially aroused the protagonist's interest in making the journey to the land of plenty and civilization. It was an accidental meeting with a French settler who persuaded him that France will make of him a man.

\begin{tabular}{|l|l|}
\hline \multicolumn{1}{|c|}{ Original French Text } & \multicolumn{1}{c|}{ English Translation } \\
\hline $\begin{array}{l}\text { [...] Si tu étais en France, tu apprendrais déjà } \\
\text { le latin et le grec, et dans dix ans tu serais } \\
\text { un homme". }\end{array}$ & $\begin{array}{l}\text { [...] If you were in France, you would already have } \\
\text { learned Greek and Latin, and in ten years you would } \\
\text { become a real man }\end{array}$ \\
(Les boucs, p. 194) & \\
\hline
\end{tabular}


As such, Les boucs features a close correlation between its form and content. The chaotic nature of immigrant life is embodied first of all in the reversing of a natural order of the first and the last chapters, in the extreme violence of the language used, in the choice of symbolically significant lexis, and in the fragmented flow of the narration. The occurrence of these stylistic markers in combination results from Chraibi's constant shifting between 'le dialogue, la narration et le monologue intérieur' (Aerts, 2016, p.18). The image conveyed is one of a vicious circle entrapping the hero.

The syntactic structure of many key passages in the novel affirms the one fact that immigrants' suffering is never-ending and gets renewed every single day. This shows most clearly in Chraibi's prepositioning of certain sentence parts and foregrounding them to draw readers' attention to their significance. Note the placement of words in the italicized part from the passage below:

\begin{tabular}{|c|c|}
\hline Original French Text & English Translation \\
\hline $\begin{array}{l}\text { La mémoire se souvenait avant même que } \\
\text { la série d'actes ne s'abattît. Longtemps } \\
\text { après, la mémoire se souvenait } \\
\text { impitoyablement du moindre détail, } \\
\text { remplissant les instants vides entre deux } \\
\text { séries d'actes - comme si du simple fait, } \\
\text { du simple désir d'oublier, de la simple } \\
\text { indifférence, naissait précisément la } \\
\text { continuité du cauchemar. (Les boucs, p. } \\
\text { 160) }\end{array}$ & $\begin{array}{l}\text { Memory recalled, even before the series of acts } \\
\text { abated. A long time afterwards, memory pitilessly } \\
\text { recaptured the most minute details and filled in } \\
\text { the empty moments between two series of acts, as } \\
\text { though the continuance of the nightmare was } \\
\text { born from the simple fact, from the simple } \\
\text { desire to forget, from a simple indifference (The } \\
\text { butts, p.109) }\end{array}$ \\
\hline
\end{tabular}

Also at the level of lexis, Chraibi's fury is felt at every word and every turn of phrase. France, the presumed 'land of plenty', is harshly denounced for breaking its promise to grant a better life to the migrants and to give them back their robbed soul. The diction and syntax of this passage generate the clearest image. Consider the imagery created by the strongly expressive lexis in the italicized parts in particular.

\begin{tabular}{|c|c|}
\hline Original French Text & English Tr \\
\hline $\begin{array}{l}\text { Parmi les } 300000 \text { Arabes de France, ils } \\
\text { étaient les résiduels, les parias. Et ils } \\
\text { n'avaient même pas à choisir entre les deux } \\
\text { attitudes possibles face au monde : } \\
\text { l'amélioration ou le défi. Non, même ce } \\
\text { choix ne leur était pas possible : ils ont } \\
\text { laissé leur âme de l'autre côté de la } \\
\text { Méditerranée. Et ils ne le savaient même } \\
\text { pas : ils se contentaient parfaitement de } \\
\text { leurs viscères. Mais tu es venu un jour leur } \\
\text { dire : vous serez des hommes, vous serez } \\
\text { heureux, vous serez libres. Prophète à taille } \\
\text { de pygmée, j'ai à t'apprendre que cette nuit } \\
\text { ils ont tué. Tué en groupe, posément, }\end{array}$ & $\begin{array}{l}\text { Among the } 300.000 \text { Arabs in France, they were the } \\
\text { residue, the outcasts. They never had the choice } \\
\text { between the two attitudes with which to confront the } \\
\text { world: change for the better or defiance. No even that } \\
\text { choice was not theirs to make: they left their soul on } \\
\text { the other side of the Mediterranean. They weren't even } \\
\text { aware of it. They were happy with their viscera. But } \\
\text { one day, you came along and told them: you will be } \\
\text { men, you will be happy, and you will be free. Prophet } \\
\text { of a pygmy's stature, you should know that that night } \\
\text { they killed. Killed as a group, delibrately, like a } \\
\text { single man, with a single knife, at the same fraction } \\
\text { of a second. Killed because they began to see the } \\
\text { soul you had given them, unsatisfied, unused, made }\end{array}$ \\
\hline
\end{tabular}

JELTL (Journal of English Language Teaching and Linguistics), 5(2), 2020 


\section{Khalid Majhad}

comme un seul homme, avec un seul them suffer too much (The butts, p.36)

couteau, à la même fraction de seconde.

Tué parce qu'ils ont commencé à

s'apercevoir que trop lourde était cette

âme que tu leur as donnée - ou redonnée

- insatisfaite, inemployée, et qu'elle les

faisait trop souffrir. (Les boucs, p. 50)

Later in a captivating poetic passage that follows, Chraibi sums up the state of disillusionment and hopelessness of the hero to receive either love or recognition in the French society. Chraibi shifts from a violent to a lyrical style while wording his emotional monologues, brooding over his own existence, his love affairs, and his concerns for his compatriots. The parallelism and assonance in the following lines is strongly captivating.

\begin{tabular}{|l|l|}
\hline \multicolumn{1}{|c|}{ Original French Text } & \multicolumn{1}{|c|}{ English Translation } \\
\hline $\begin{array}{l}\text { Je ne veux pas aimer, cria-t-il... Je ne } \\
\text { veux pas l'aimer... Je ne peux plus }\end{array}$ & $\begin{array}{l}\text { I don't want to love, he cried, I don't want to } \\
\text { love her...I don't want to love anymore...Even } \\
\text { aimer... Même si c'est une femme toute } \\
\text { if she were a pure woman, even if she were }\end{array}$ \\
pure, même si elle n'a rien de commun \\
avec celle qui m'a chassé... Boire, je dois \\
boire... Boire et tuer en moi tout espoir \\
$\begin{array}{l}\text { de rachat et rester un schéma de dike the one who threw me } \\
\text { out...Drink, I need a drink...I want to drink } \\
\text { and destroy in myself any hope of redemption } \\
\text { and go on being just an Arabo... (The butts, p. }\end{array}$ \\
\begin{tabular}{l}
$106)$ \\
\hline Les boucs, p.155)
\end{tabular}
\end{tabular}

Chraibi's judicious choice of the right lexical items serves to convey the idea that that the suffering is not so much physical as it is really psychological. This idea is well expressed by means of the polysemous French verb se meurtrir which denotes physical as well as emotional pain.

\section{À force de se meurtrir}

\section{By beating his hands black and blue,}

\begin{tabular}{|l|l|}
\hline \multicolumn{1}{|c|}{ Original French Text } & \multicolumn{1}{|c|}{ English Translation } \\
\hline $\begin{array}{c}\text { Se répétant qu'à force de se meurtrir il } \\
\text { parviendrait sans doute à dépasser la }\end{array}$ & $\begin{array}{l}\text { She kept telling herself that perhaps by beating his } \\
\text { hands black and blue, he would finally go beyond }\end{array}$ \\
souffrance. Oui, pensait-elle, si les chiens & suffering. Yes, she thought, if dogs can go beyond the \\
arrivaient à dépasser cette condition de & fate of being the dogs that men have made of them, \\
chiens que les hommes leur ont faite, mais & keeping them shut up and and showing them so much \\
où ils se cloisonnent et qu'ils affectionnent & affection, they would turn into wolves. (The butts, p. \\
si profondément, ils se retrouveraient loups. & $115)$ \\
(Les boucs, p. 169) &
\end{tabular}

At no point does Chraibi disguise his disenchantment with France's dehumanizing maltreatment of North African immigrants who had come to it with high hopes; He lets readers recognize that the suffering is not so much physical as it is psychological. Once 
again, the emphatic prepositioning of the sentence predicate (in bold) is indicative of Chraibi's indignation about the immigrants' self-loss once they set foot on French soil, hence his warning for his compatriots back home to 'send their shoes instead of themselves' [d'y expédier simplement leurs souliers].

\begin{tabular}{|c|c|}
\hline Original French Text & English Translation \\
\hline $\begin{array}{l}\text { Je ne dirais jamais à ceux qui sont restés en } \\
\text { Afrique que travaille comme un ténia le } \\
\text { mirage de l'Europe, d'y expédier } \\
\text { simplement leurs souliers : tout ce que } \\
\text { peut faire un Bicot en Europe : marcher -à } \\
\text { la recherche du bonheur; (Les boucs, p. } 88)\end{array}$ & $\begin{array}{l}\text { I would never tell people who have stayed in Africa } \\
\text { that the mirage of Europe eats like a tapeworm, to } \\
\text { send their shoes instead of themselves. The only thing } \\
\text { an Arabo can do is to walk - in search of happiness. } \\
\text { (The butts, } p .60 \text { ) }\end{array}$ \\
\hline
\end{tabular}

On another level, the colonial past of France is a key contextual element that says a great deal about the constant tension between the colonizer and colonized, even in today's metropolitan French society. Chraibi emphasizes the domineering colonial tone in the way French officials address the immigrants. In one interaction with a newly arriving immigrant, the French official gives orders in Algerian dialect Roh! fissa!, which, read in light of surrounding co-text, shows an arrogant attitude towards inferior 'uncivilized' Maghrebian immigrants. It is an expression the common Algerian typically uses to give orders to kids.

\begin{tabular}{|c|c|}
\hline Original French Text & English Translation \\
\hline Monsieur le commissaire... & Monsieur Commissioner \\
- Demain, j'ai dit. Roh ! fissa ! & (Les boucs, p. 104) \\
& (The butts, p. 72) \\
\hline
\end{tabular}

The above stylistic features attest to a modernist spirit of Chraibi's writing whose main characteristic is the absence of a clear chronological succession of events, the abundant use of irony and the predominance of character internal monologues in which they brood over their concerns. Aerts provides the following technical description of modernist wrining in general, of which Les bouc is a specimen:

\begin{tabular}{|c|c|}
\hline Original French Text & English Translation \\
\hline $\begin{array}{l}\text { Si le roman classique suit une certaine } \\
\text { chronologie, le roman moderniste s'interroge } \\
\text { (ou se moque peut-être) de la nécessité de } \\
\text { maintenir cette structure. Les Boucs lui aussi } \\
\text { contient un récit non linéaire, ce qui a } \\
\text { compliqué la lecture. (p.16). } \\
\text { Un autre effet qui est causé par le } \\
\text { renversement de l'ordre des chapitres, est } \\
\text { l'ironie. Le lecteur traverse d'abord les } \\
\text { errances de Waldik, les années en prison, la } \\
\text { relation difficile avec Simone et la misère } \\
\text { qu'il a vécue en habitant avec les Boucs. Puis } \\
\text { à la fin du livre, le lecteur apprend la raison }\end{array}$ & $\begin{array}{l}\text { If the classic novel follows a certain chronology, the } \\
\text { modernist novel is indifferent to the need to maintain } \\
\text { this structure. Les boucs contains a non-linear } \\
\text { narrative which poses complicated reading task. } \\
\text { Another effect that is caused by the reversal of the } \\
\text { order of chapters is irony. } \\
\text { After reading through Waldik's wanderings, years in } \\
\text { prison, his difficult relationship with Simone and the } \\
\text { misery he experienced while living with the } \\
\text { immigrants, the reader reaches the end of the book } \\
\text { where he discovers the motive behind Yalaan's } \\
\text { decision to emigrate to France: the promise made to } \\
\text { him by a priest of a better life in the metropolis (My }\end{array}$ \\
\hline
\end{tabular}






\subsection{Immigrant Life in Begag's Narrative: A Cognitive Stylistic Analysis}

In contrast to the bleak picture presented throughout Chraibi's text, Begag's convivial approach oozes hope for a reader who has been in similar conditions. Begag's narrative deals specifically with the inner troubles related to the issue of acknowledging one's identity. The life of Begag at school was seriously beset each time he has to lie about or avoid revealing his true ethnic belonging. He mentions the memorable incident when, against the background of the Arab-Israeli War in 1967, he had to claim he was Jewish in order to avoid denigration of his Arab-ness. To survive in a such a 'hostile' society, or so believed it is, the children of immigrants are forced everyday to behave in a 'chameleonlike' fashion to avoid denigration. They therefore adopt a 'camouflage' strategy whereby they try to conform to 'the environment of the given moment $[\ldots]$ and live a life straddled between two discrete worlds, one entirely Muslim Algerian and the other entirely secular French' (p.219).What makes Begag's text a pleasurable and insightful read is the smooth flow and humorous tone of the narration, written in an accessible and engaging style allowing world readers of deprived backgrounds to identify with the events and the authors life milestones that contributed to his future glamorous career.

\begin{tabular}{|c|c|}
\hline Original French Text & English Translation \\
\hline $\begin{array}{l}\text { - T'es un Arabe ou un juif, toi ? Me } \\
\text { questionne l'aîné des Taboul, alors que nous } \\
\text { sommes en recréation...Depuis que la } \\
\text { terrible question a été posée, j'ai eu le } \\
\text { temps de réfléchir à mille conséquences } \\
\text { de ma réponse, en une fraction de } \\
\text { seconde. Il ne faut pas donner l'impression } \\
\text { d'hésiter. -Je suis juif ! dis-je, convaincu. } \\
\text {...Je suis juif, j'ai dit. Si j'avais avoué que } \\
\text { j'étais arabe, tout le monde m'aurait mis en } \\
\text { quarantaine, à part Barbar, bien sur. (Le } \\
\text { gone du Chaaba, p. 106). }\end{array}$ & $\begin{array}{l}\text { Are you an Arab or a Jew? Asked the eldest of the } \\
\text { Taboul brothers during recess ... I had to quickly } \\
\text { weigh the many consequences of my answer. So, } \\
\text { without giving the impression of being hesitant, I } \\
\text { said. -I'm Jewish ! I am Jewish. If I had confessed } \\
\text { that I was Arab, everyone would have have begun to } \\
\text { think of me as nothing but Barbarous. } \\
\text { (My Trans.) }\end{array}$ \\
\hline
\end{tabular}

While young Begag is ashamed of declaring his Arab origin, he is so excited to tell his teacher he was born in France.

\begin{tabular}{|l|l|}
\hline \multicolumn{1}{|c|}{ Original French Text } & \multicolumn{1}{|c|}{ English Translation } \\
\hline Elle a demandé à quel âge j'étais arrivé & She asked how old I was when I came to France from \\
d'Algérie, et alors là j'ai fait observer avec & Algeria. I proudly replied that I was actually born \\
fierté que j'avais vu le jour à Lyon, dans le & in Lyon, in the largest hospital Grache-Blache. (My \\
plus grand hôpital : Grache-Blache. (Le gone du & Trans.) \\
Chaaba 193). & \\
\hline
\end{tabular}


Young Begag's fear of exposing his true identity extends to his writing assignments in which he had to envisage a different person other than himself.

\begin{tabular}{|c|c|}
\hline Original French Text & English Translation \\
\hline $\begin{array}{l}\text { Le maître annonce que, jusqu'à } 11 \mathrm{~h} 30 \text {, nous allons } \\
\text { faire } \\
\text { une rédaction. Sujet : " Racontez une journée de } \\
\text { vacances à la campagne. » Je sors de mon cartable une } \\
\text { feuille double, plante ma plume dans l'encrier et } \\
\text { démarre sans brouillon ma composition. Mes idées } \\
\text { sont déjà ordonnées. Je ne peux pas lui parler du } \\
\text { Chaâba, mais je vais faire comme si c'était la } \\
\text { campagne, celle qu'il imagine (Le gone du Chaaba, p. } \\
\text { 32). }\end{array}$ & $\begin{array}{l}\text { The teacher announced that we will write an } \\
\text { essay, the topic of which was 'tell about a } \\
\text { holiday in the countryside. I took out a double } \\
\text { sheet from my schoolbag and started my } \\
\text { composition without a draft, but. I could not talk } \\
\text { to him about Chaâba; I'd pretend it was } \\
\text { somewhere in the countryside, some place he } \\
\text { can readily visualize. (My Trans.) }\end{array}$ \\
\hline
\end{tabular}

Ultimately, however, Azouz sends the interesting message that only by acknowledging one's identity and starting from there can we achieve success. He begins to realize the futility of continuing to curse the state of deprivation and inequity suffered by the community of Maghrebian immigrants while there can always be ways setbacks can be turned into opportunities. He proudly presents himself and his father as living examples. He keeps reiterating his father's sacrifice and determination to grant his children a good education despite all odds.

\begin{tabular}{|l|l|}
\hline \multicolumn{1}{|c|}{ Original French Text } & \multicolumn{1}{c|}{ English Translation } \\
\hline Je préfère que vous travailliez à l'école. Moi je vais & $\begin{array}{l}\text { You work at school; I work at the factory for } \\
\text { à l'usine pour vous, je me crèverai s'il le faut, mais } \\
\text { je ne veux pas que vous soyez ce que je suis, un } \\
\text { you, I'll be ready to die if I have to, but I do not } \\
\text { pauvre travailleur. Si vous manquez d'argent, je vous } \\
\text { en donnerai, mais je ne veux pas entendre parler de } \\
\text { marché. (Le gone du Chat I am, a poor worker. If you } \\
\text { run of money, I'll give you some, but I do } \\
\text { not want to hear anything about you going to the } \\
\text { market. (My Trans.) }\end{array}$ \\
\hline
\end{tabular}

Young Azouz, receptive to his father's supportive words, eventually decides to surmount the excessively defeatist attitudes shackling all possibility of change in his diffident community, and sets off on a successful schooling journey that would allow him to be the man generations before him had wished him and his compatriots to be.

\begin{tabular}{|c|c|}
\hline Original French Text & English Translation \\
\hline $\begin{array}{l}\text { J'ai honte de mon ignorance. Depuis quelques } \\
\text { mois, j'ai décidé de changer de peau. Je n'aime } \\
\text { pas être avec les pauvres, les faibles de la } \\
\text { classe. Je veux être dans les premières places } \\
\text { du classement, comme les Français (Le gone du } \\
\text { Chaaba, p. 58) }\end{array}$ & $\begin{array}{l}\text { I am ashamed of my ignorance. A few months } \\
\text { ago, I decided to change my skin. I do not like } \\
\text { being with the poor, the weak in the class. I } \\
\text { want to be on top of the ranking, like the French. } \\
\text { (My Trans.) }\end{array}$ \\
\hline
\end{tabular}

\subsection{Immigrant Life on The ground: A Visitor's Perspective}

For a reader who has been to France, these two novels would certainly conjure up concrete images of a reality perfectly twisted by French mainstream media about the undesired presence of immigrants. There is a hidden psychological dimension to the 


\section{Khalid Majhad}

disturbed life of immigrants that maximizes their sense of inferiority and fuels their anger and aggressiveness. Suffice it to mention that no matter how effective your presence is within the French society you are always vulnerable to contemptuous gazes each time the media reports on some criminal or terrorist act anywhere in the world. On the ground, a thoughtful visitor would get bothered by the many 'mild' hostilities against immigrants and their descendants. One would also suspect if it is only a matter of coincidence that white blond-haired French school kids would not hold hands with immigrant kids while marching in line on an excursion.

Immigrants lead a life in France that is more akin to a chaotic circle, just like the picture Chraibi does perfectly convey when he unconventionally leaves until the closing chapter a key passage about the origin of the idea of immigration, that which should have been placed first. Aerts (2016) adds that 'la situation des immigrés nord-africains ne s'améliore pas, puisque le récit ne se développe pas du tout. Au lieu d'avancer, ils semblent se trouver dans une stagnation permanente'(p.14) [the situation of North African immigrants does not improve, as their story does not develop at all. Instead of moving forward, they seem to linger in permanent stagnation] (My Trans.). Joining him is Duffy (2017) who evokes Julia Kristeva's metaphor likening the immigrant to the orphaned traveler 'who has lost a 'home' country, but to whom the 'adopted' country grants only visitor status, the traveler being always expected to move on, denied the comfort of acceptance [...] His happiness consists of ebbs and flows as he dreams of a life beyond' the transitory' (p.219).

\section{DISCUSSION}

This article has advanced an argument about the need for a re-evaluation of the situation of immigrants on the basis of an open debate involving voices from all hues of French Metropolitan society. Chraibi and Begag are the kind of organic intellectuals whose views we must heed for an alternative approach to resolving the undeniably existing tension. Read in reversed chronological order, young Begag seems to be fulfilling the suppressed wishes of his ancestors represented by Chraibi.

Though on the surface Les Boucs is perceived as a harsh critique against metropolitan France which has turned its promise of a better existence for immigrants into a daily lived nightmare, it is at a deeper level, Les boucs is 'Les boucs is 'a novel in search of love and reconciliation' (Bencheikh, 1996, para. 5). Begag, on the other hand, comes in with an alternative stance preaching hope among his compatriots and calling for the elimination of defeatist and negative attitudes.

Generally, in France and elsewhere, immigrant life is not without costs. The cultural clash is the first hindrance to comfortable integration. Begag's father offers a role model for all immigrants to follow in that ensuring a good education for one's kids is the best gift parents could provide to help raise them with a healthy reasoning about their presence side by side with the western Other. The metaphorical passage from frustrated Chraibi to hopeful Begag has been encumbered with incredible difficulties, but their journeys end at a point where determination and good life management surmount all odds, with Chraibi attaining utmost fame as a world-renowned writer and Begag becoming a minister. 
The study has also proposed and applied an arguably effective mode of reading inspired by cognitive stylistics. The multilevel analyses above have shown that stylistically aware readings of the literary text lead to meaningful and plausible interpretations.

\section{CONCLUSION}

The Maghrebian novel, a most popular genre, has in large part assumed the function of a commentary on the various issues affecting Maghrebians in colonial and postcolonial times, to the extent that many would argue that the novel with its minute social and cultural details is the best place for one to discover and rediscover the Maghreb. This article has chosen to probe the specificities of Maghrebians' immigrant life in metropolitan France from the viewpoint of two autobiographical novels by two internationally recognized Maghrebian novelists who respectively represent the first and second generations of Maghrebian immigrants in France. Cognitive stylistics is the chosen framework for our qualitative reading of the two novels. Though misgivings are frequently expressed about the lack of scientific objectivity in qualitative methods, the study has sought to ensure the validity of its qualitative analyses by means of extensive 'contextualization' and analytical 'comprehensiveness'. The stylistic features singled out above are indicative of authorial angles of vision in that they 'represent not only different ways of saying the same thing but different ways of saying which reflect different ways of seeing' (BoaseBeier, 2010, p. 110).

\section{REFERENCES}

Aerts, V. S. (2016). L'immigration maghrébine vue au miroir du roman Driss Chraïbi, Les Boucs (1955) et Tahar ben Jelloun, Au Pays (2009) ; une étude comparée. Unpublished Dissertation. Université de Leyde.

Bahria, H. (2014). Civilization and Otherness: The case of Driss Chraibi. Journal of arts and humanities, 3(1): 64-69.

Begag, A. (1986). Le Gone du Chaâba. Edition du seuil

Ben Mbarek, A. (2015). Littérarité et interculturalité dans l'œuvre de Driss Chraibi «Le passé simple». Unpublished Dissertation. Université Mohamed Kkhider: Faculté des Lettres et des Langues- Biskra

Bencheikh, M. (1996). Driss Chraïbi. Retrieved from http://www.limag.refer.org/Textes/Manuref/Chraibi.htm

Boase-Beier, J. (2010). Stylistic approaches to translation. London \& New York: Routledge. Cailler, B. (1996). Entre culture et barbarie, enchantement et désenchantement: Les Boucs de Driss Chraïbi (1955). Revue CMC Review, 3(1): 1-18.

Chraibi, D. (1983). The butts.(H. Harter, Trans.).Three Continents Press

Chraibi, D. (1955). Les boucs. Denoël

Duffy, P. (2017). The motif of 'crossings' in selected works by Azouz Begag. French Cultural Studies, 28 (2): 218-237.

Ghazala, H. (2011). Cognitive stylistics and the translator. Sayyab Books Ltd.

Lay-Chenchabi, K., \& Do, T. (2011). Guilt and betrayal in the works of Azouz Begag and Linda Lê. French Cultural Studies 19(1): 39-56. 


\section{Khalid Majhad}

Moukhlis, M. S. (2001). Driss Chraibi. In C. J. Hawley. (Ed.). Encyclopedia of Postcolonial Studies. London: Greenwood Press.

Orlando, V. (2001). Beur writing. In C. J. Hawley. (Ed.). Encyclopedia of postcolonial studies. London: Greenwood Press.

Saldanha, G. \& O'Brien, S. (2013). Research methodologies in translation studies. London \& New York: Routledge. 